Brit. J. industr. Med., 1949, 6, 241.

\title{
SILICOSIS IN SANDSTONE WORKERS SOME OBSERVATIONS BASED ON TWO HUNDRED AND SEVENTY-FIVE NECROPSIES
}

\author{
BY \\ A. MEIKLEJOHN \\ Sometime member of the Medical Board for Silicosis, Stoke-on-Trent \\ (RECEIVED FOR PUBLICATION APRIL 2, 1949)
}

As a supplement to the preceding article on silicosis in pottery workers, a similar analysis has been applied to 275 necropsies occurring during the same period in several occupational groups, banker-masons, stone-dressers and cutters, metalgrinders, sandblasters, steel-fettlers, and coalminers. All are exposed to the same hazard, namely, the inhalation of silica dust arising out of the use and manipulation of sandstone and its derivatives.

TABLE 1

DISTRIBUTION BY OCCUPATION

\begin{tabular}{lcccc|c}
\hline & & & $\begin{array}{c}\text { No. } \\
\text { of } \\
\text { cases }\end{array}$ \\
\hline Banker-mason & $\ldots$ & $\ldots$ & $\ldots$ & $\ldots$ & 57 \\
\hline Stone-dresser and cutter &. & $\ldots$ & $\ldots$ & 50 \\
\hline Metal-grinder & $\ldots$ & $\ldots$ & $\ldots$ & $\ldots$ & 29 \\
\hline Sandblaster.. & $\ldots$ & $\ldots$ & $\ldots$ & $\ldots$ & 26 \\
\hline Steel-fettler.. & $\ldots$ & $\ldots$ & $\ldots$ & $\ldots$ & 7 \\
\hline Coal-miner.. & $\ldots$ & $\ldots$ & $\ldots$ & $\ldots$ & 106 \\
\hline All occupations & $\ldots$ & $\ldots$ & $\ldots$ & $\ldots$ & 275 \\
\hline
\end{tabular}

\section{Description of Occupations}

Banker-mason.-This occupation comprises the shaping and dressing of rock, sandstone, limestone, marble, and granite for monumental purposes such as public buildings and bridges. The essential characteristic of the work is that each stone is fashioned by mallet and chisel to a size and design specified on an architect's blueprint. The masons in the group were employed in Cheshire, Staffordshire, and Derbyshire.

Stone-dresser and Cutter.-This work is similar to that described above but is restricted to dividing large blocks' of stone and roughly shaping them by hammer and punch. The operations are frequently carried out at the quarries, and common products are wallstones, kerbs, setts, and grindstones. This group also is derived from the counties mentioned.

Metal-grinders.-This work involves the grinding of metals on grindstones composed of natural sandstone. The industry is mainly concentrated in Sheffield, but this particular group was employed in the manufacture of edge tools in and around Wolverhampton and Birmingham.

Sandblaster.-This group was employed at various. foundries in the Midlands engaged in the cleaning of castings by means of dried quartzose sand.

Steel-fettler.-This work involves the freeing of steel castings from adherent sand by means of hand, pneumatic, or power-driven tools.

Coal-miner.-This group is restricted to underground workers, and so far as dust disease of the lungs is involved relates only to silicosis; dust reticulation is not considered. The men were employed in North and South Staffordshire.

TABLE 2

CERTIFIED CAUSE OF DEATH

\begin{tabular}{|c|c|c|c|c|}
\hline \multicolumn{2}{|c|}{ Cause of death } & $\begin{array}{l}\text { No. } \\
\text { of } \\
\text { cases }\end{array}$ & $\%$ & $\begin{array}{c}\text { Pottery } \\
\text { survey } \\
\%\end{array}$ \\
\hline Silicosis .. & . $\quad \ldots$ & 76 & $27 \cdot 6$ & $28 \cdot 9$ \\
\hline $\begin{array}{l}\text { Silicosis accor } \\
\text { tuberculosis }\end{array}$ & $\begin{array}{cc}\text { anied by } \\
\ldots\end{array}$ & 93 & $33 \cdot 8$ & $32 \cdot 1$ \\
\hline $\begin{array}{l}\text { Other causes ( } \\
\text { present) }\end{array}$ & $\begin{array}{l}\text { cosis } \\
\therefore\end{array}$ & 41 & $14 \cdot 9$ & $19 \cdot 0$ \\
\hline Other causes & silicosis) & 65 & $23 \cdot 7$ & $20 \cdot 0$ \\
\hline All causes & .. & 275 & $100 \cdot 0$ & $100 \cdot 0$ \\
\hline
\end{tabular}




\section{Analysis and Commentary}

The 275 necropsies completed under the direction of H.M. Coroner were distributed as shown in Table 1. As in the previous survey the cause of death is related to silicosis or other causes (Table 2). The distribution in the two surveys is remarkably parallel (Table 3).

\section{Silicosis Accompanied by Tuberculosis}

In this context tuberculosis means active tuberculosis of the lungs with tubercle bacilli present in the sputum, and in ninety-three cases the combined disease, silicosis accompanied by tuberculosis, was the cause of death. The distribution of these by age group and occupation is set out in Table 4.

TABLE 3

CAUSE OF DEATH ACCORDING TO OCCUPATION

\begin{tabular}{|c|c|c|c|c|c|c|c|c|}
\hline \multirow{2}{*}{\multicolumn{4}{|c|}{ Occupation }} & \multicolumn{4}{|c|}{ Cause of death } & \multirow{2}{*}{$\begin{array}{c}\text { All } \\
\text { causes }\end{array}$} \\
\hline & & & & Silicosis & \multirow{2}{*}{$\begin{array}{c}\begin{array}{c}\text { Silicosis }+ \\
\text { tuberculosis }\end{array} \\
21\end{array}$} & \multirow{2}{*}{\begin{tabular}{|c|}
$\begin{array}{c}\text { Other causes } \\
\text { (Silicosis present) }\end{array}$ \\
12 \\
\end{tabular}} & \multirow{2}{*}{$\frac{\begin{array}{c}\text { Other causes } \\
\text { (no Silicosis) }\end{array}}{7}$} & \\
\hline Banker-mason & . & . & $\cdots$ & 17 & & & & 57 \\
\hline Stone-dresser ar & ad cutte & & . & 15 & 18 & 12 & 5 & 50 \\
\hline Metal-grinder & . & . & $\cdots$ & 12 & 11 & 4 & 2 & 29 \\
\hline Sandblaster & $\cdots$ & . & $\cdots$ & 5 & 18 & 1 & 2 & 26 \\
\hline Steel-fettler & . & . & $\ldots$ & 2 & 5 & - & - & 7 \\
\hline Coal-miner & . & . & $\cdots$ & 25 . & 20 & 12 & 49 & 106 \\
\hline All occupations & . & $\ldots$ & $\ldots \cdot$ & 76 & 93 & 41 & 65 & 275 \\
\hline
\end{tabular}

TABLE 4

AGE AT DEATH IN RELATION TO OCCUPATION

\begin{tabular}{|c|c|c|c|c|c|c|c|}
\hline \multirow[b]{2}{*}{ Age group } & \multicolumn{6}{|c|}{ Occupation } & \multirow{2}{*}{ All } \\
\hline & $\begin{array}{c}\text { Banker- } \\
\text { mason }\end{array}$ & $\begin{array}{l}\text { Stone- } \\
\text { dresser }\end{array}$ & $\underset{\text { grinder }}{\text { Metal }}$ & $\begin{array}{c}\text { Sand- } \\
\text { blaster }\end{array}$ & $\begin{array}{l}\text { Steel- } \\
\text { fettler }\end{array}$ & $\begin{array}{l}\text { Coal- } \\
\text { miner }\end{array}$ & \\
\hline Under 20 & - & - & - & 一 & - & - & - \\
\hline $20-24 \ldots$ & - & - & - & - & - & - & - \\
\hline $25-29$ & - & 1 & - & 2 & - & 1 & 4 \\
\hline $30-34 \ldots$ & 一 & 1 & 一 & 2 & - & - & 3 \\
\hline $35-39 \ldots$ & - & - & 3 & 2 & - & 1 & 6 \\
\hline $40-44 \ldots$ & 2 & 1 & - & 3 & 3 & 1 & 10 \\
\hline $45-49 \ldots$ & 1 & 2 & 2 & 5 & 一 & 1 & 11 \\
\hline $50-54 \ldots$ & 5 & 3 & 1 & 2 & - & 3 & 14 \\
\hline $55-59 \ldots$ & 5 & 4 & 2 & - & 1 & 4 & 16 \\
\hline $60-64 \ldots$ & 4 & 2 & 3 & 2 & - & 3 & 14 \\
\hline $65-69 \ldots$ & 4 & 3 & - & - & 1 & 6 & 14 \\
\hline $70+\ldots$ & - & 1 & - & - & - & - & 1 \\
\hline All ages & 21 & 18 & 11 & 18 & 5 & 20 & 93 \\
\hline
\end{tabular}


While the high incidence of tuberculosis in late middle life again appears (Table 5), the occurrence of cases in sandblasters under the age of $\mathbf{4 0}$ years is serious, a matter which has been remarked upon by Merewether (1936) and which appears in th Annual Reports of H.M. Chief Inpsector Factories (1933 et seq.).

TABLE 5

DEGREE OF SILICOSIS ASSOCIATED WITH FATAL TUBERCULOSIS

\begin{tabular}{|c|c|c|c|c|}
\hline \multirow[b]{2}{*}{ Occupation } & \multicolumn{3}{|c|}{ Degree of silicosis } & \multirow[b]{2}{*}{ Total } \\
\hline & $\begin{array}{l}\text { Micro- } \\
\text { scopic }\end{array}$ & $\begin{array}{l}\text { Nodu- } \\
\text { lar }\end{array}$ & $\begin{array}{l}\text { Con- } \\
\text { fluent }\end{array}$ & \\
\hline Banker-mason .. & 3 & 7 & 11 & 21 \\
\hline Stone-dresser $\ldots$ & 1 & 7 & 10 & 18 \\
\hline Metal-grinder .. & .2 & 5 & 4 & 11 \\
\hline Sandblaster & 4 & 8 & 6 & 18 \\
\hline Steel-fettler & - & 2 & 3 & 5 \\
\hline Coal-miner & 1 & 6 & 13 & 20 \\
\hline All occupations & 11 & 35 & 47 & 93 \\
\hline
\end{tabular}

It is confirmed that fatal tuberculosis may emerge even when the degree of silicosis is minimal though most commonly the association is with massive fibrosis. Sandblasters again appear exceptional, but the absolute numbers are too small to justify any definite conclusions. As shown in Table 3, there was evidence of silicosis in 210 cases, and in ninety-three cases this was combined with active tuberculosis, which represents an incidence of $44 \cdot 3$ per cent. ; the corresponding figure among pottery workers was 40 per cent. This contrasts with the recorded opinion of authorities in Great Britain (Bridge, 1931; Sutherland, 1945; Hale, 1945), South Africa (Simson and others, 1930), and France (Deffrenne, 1945), who place the incidence between 46 and 75 per cent.

In view of the tentative explanation advanced in respect of pottery workers it appeared worth while to relate tuberculosis in silicosis with age incidence, but to ensure uniformity it was deemed advisable to restrict the analysis to male workers. The analysis covers the pottery workers $(P)$ and the miscellaneous group of occupations (M) (Table 6).

The diminishing influence of tuberculosis as the cause of death with the advance of age is apparent and supports a hypothesis which was formulated

TABLE 6

FATAL TUBERCULOSIS COMPLICATING SILICOSIS

\begin{tabular}{|c|c|c|c|c|c|c|c|c|c|c|c|c|}
\hline \multirow{2}{*}{\multicolumn{2}{|c|}{ Age group }} & \multicolumn{3}{|c|}{ Silicosis } & \multicolumn{3}{|c|}{$\begin{array}{c}\text { Other causes } \\
\text { (Silicosis present) }\end{array}$} & \multicolumn{3}{|c|}{$\begin{array}{l}\text { Silicosis + } \\
\text { tuberculosis }\end{array}$} & \multirow{2}{*}{$\begin{array}{c}\text { All cases } \\
\text { with evidence } \\
\text { of silicosis }\end{array}$} & \multirow{2}{*}{$\begin{array}{c}\% \text { Silicosis }+ \\
\text { tuberculosis } \\
\text { to silicosis }\end{array}$} \\
\hline & & $\mathbf{P}$ & $\mathbf{M}$ & Total & $\mathbf{P}$ & $\mathbf{M}$ & Total & $\mathbf{P}$ & $\mathbf{M}$ & Total & & \\
\hline Under 20 & $\cdots$ & - & - & - & - & - & - & - & - & - & - & - \\
\hline $20-24 \ldots$ & $\cdots$ & - & - & - & - & - & - & - & - & - & - & - \\
\hline $25-29 \ldots$ & $\cdots$ & - & - & - & - & - & - & 一 & 4 & 4 & 4 & $100 \cdot 0$ \\
\hline $30-34 \ldots$ & $\ldots$ & - & 1 & 1 & - & 1 & 1 & 2 & 3 & 5 & 7 & $71 \cdot 4$ \\
\hline $35-39 \ldots$ & $\cdots$ & - & 3 & 3 & - & 1 & 1 & 5 & 6 & 11 & 15 & $73 \cdot 3$ \\
\hline $40-44 \ldots$ & $\cdots$ & 7 & 7 & 14 & 5 & 1 & 6 & 22 & 10 & 32 & 52 & $61 \cdot 5$ \\
\hline $45-49 \ldots$ & $\cdots$ & 7 & 4 & 11 & 10 & 3 & 13 & 16 & 11 & 27 & 51 & $52 \cdot 9$ \\
\hline $50-54 \ldots$ & . & 27 & 21 & 48 & 17 & 11 & 28 & 43 & 94 & 57 & 133 & $43 \cdot 1$ \\
\hline $55-59 \ldots$ & $\cdots$ & 39 & 17 & 56 & 22 & 8 & 30 & 33 & 16 & 49 & 135 & $36 \cdot 3$ \\
\hline $60-64 \ldots$ & . & 52 & 10 & 62 & 37 & 10 & 47 & 36 & 14 & 50 & 159 & $32 \cdot 1$ \\
\hline $65-69 \ldots$ & $\cdots$ & 51 & 8 & 59 & 23 & 2 & 25 & 36 & 14 & 50 & 134 & $37 \cdot 3$ \\
\hline $70+\ldots$ & . & 18 & 5 & 23 & 24 & 5 & 29 & 14 & 1 & 15 & 67 & $22 \cdot 4$ \\
\hline All ages & $\cdots$ & 201 & 76 & 277 & 138 & 42 & 180 & 207 & 93 & 300 & 757 & $39 \cdot 7$ \\
\hline
\end{tabular}


TABLE 7

PRIMARY BRONCHIAL CARCINOMA (NO SILICOSIS)

\begin{tabular}{c|c|c|c|c|c|c}
\hline No. & Initials & Occupation & Age & Lung & Remote metastases & Remarks \\
\hline 1 & W. N. & Metal grinder & 47 & R & Liver & T.B. plus \\
\hline 2 & E. S. G. & Banker-mason & 67 & R & Liver & - \\
\hline 3 & J. G. G. & Collier & 54 & R & None & - \\
\hline 4 & G. F. B. & Collier & 57 & L & None & - \\
\hline 5 & J. H. S. & Collier & 62 & R & Liver & - \\
\hline 6 & E. W. G. & Collier & 39 & R & None & - \\
\hline
\end{tabular}

TABLE 8

PRIMARY BRONCHIAL CARCINOMA (SILICOSIS PRESENT)

\begin{tabular}{c|c|c|c|c|c|c}
\hline No. & Initials & Occupation & Age & Lung & Remote metastases & Remarks \\
\hline 1 & A. T. & Banker-mason & 53 & R & None \\
\hline 2 & A. M. & Banker-mason & 56 & R & None & None \\
\hline 3 & J. M. & Banker-mason & 56 & L & R. \\
\hline 4 & H. E. M. & Metal grinder & 52 & R & None \\
\hline
\end{tabular}

from clinical observation. At the same time it helps to reconcile the divergent opinion of authorities. Maybe the real value is that the details may provide comparative data for other workers concerned with the cognate problems of the relationship of tuberculosis to asbestosis and dust reticulation of coal-miners, problems which are of vital practical importance and not merely of academic interest.

As to the further analyses of this series of 275 necropsies, precisely similar methods have been applied as were used for the 750 necropsies in pottery workers. The results coincide so closely that no useful purpose would be served by recording them in detail.

Primary bronchial carcinoma, however, is a subject of considerable interest to many observers at the present time so the details may be justified for reference.

In sixty-five cases death was due to "other causes" without any evidence of silicosis, and among these were six cases of primary bronchial carcinoma ; in one it was associated with active pulmonary tuberculosis (T.B. plus) (Table 7).

Among the 210 cases in which there was evidence of silicosis in some degree were four cases of primary bronchial carcinoma, of which one was associated with silicosis accompanied by tuberculosis (T.B. plus) (Table 8).

\section{Summary}

In a previous communication an analysis was made of 750 necropsies in pottery workers with special reference to silicosis and related problems.

This is supplemented by a similar analysis of 275 necropsies in a miscellaneous group of occupations involving exposure to siliceous dust produced in the manipulation and use of sandstone and its derivatives.

Further attention is directed to tuberculosis occurring as a complication of silicosis, and details are given of ten cases of primary bronchial carcinoma.

\section{REFERENCES}

Bridge, J. C. (1931). Ann. Rep. Senior Med. Inspector of Factories. H.M. Stationery Office. p. 74.

Deffrenne, P. (1945). "Contribution a L'Etude Du Prognostic Clinique De La Silicose Chez Les Mineurs Au Rocher." Imprimiere Reginer, Chavany et Cie, Lyon.

Imprimiere Reginer, Chavany et Cie,
Hale, L. W. (1945). Brit. J. Tuberc., 39, 91 .

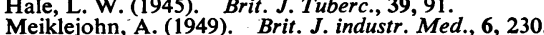

Meiklejohn, A. (1949). Brit. J. industr. Med., 6, 230.

Merewether, E. R. A. (1936). Tubercle, 17, 385. in South Africa." A. S., and Irvine, L. G. (1930). " Silicosis Transvaal Mine Medical Officers' Association (Special Supplement).

Sutherland, C. L. (1945). Proc. R. Soc. Med., 38, 519. 